\title{
The Research on the Problems and Countermeasures of College Counselors' Career Development
}

\author{
Chao Wang ${ }^{1, a}$ and Junzheng Wang ${ }^{1, \text { b* }}$ \\ ${ }^{1}$ Xincheng Street 2888, Jilin Agricultural University, Changchun, Jilin Province 130118, PR China \\ a29251275@qq.com, b59545966 @ qq.com \\ *The corresponding author
}

Keywords: College counselors; Career development; Problems; Strategies; Research

\begin{abstract}
Ideological and political education is the prime work of the college to cultivate socialist successors and it's the top priority among college work. College counselors are the backbone to promote the ideological and political education and it is also counselors who guide the students to form correct socialist outlooks on life, value and world. Through analyzing the current status of college counselors' development, relevant measures are put forward to promote the development and the team construction of college counselors' professionalization.

It is stated explicitly in The Standards of College Counselors' Professional Competence (Interim) that college counselors are the professionals who are in charge of students' work; they need systematic training, good professional ethics as well; they should master knowledge and skills which are systematic professional. The document describes a grand blueprint for the development of the college counselors. First, it establishes the concept of counselors' career development, improves counselors' credibility, career status and professional self-identity. Second, it strengthens the policy of college counselors' team construction, sets up and improves professional system of the access, appraisal, training, development and demission. Third, it enriches the connotation of the counselors' work and guides counselors to actively improve their professional literacy and vocational ability. Forth, it defines the scope and border of the work and figures out counselors' responsibility in practical work.
\end{abstract}

\section{Present Problems in Counselors' Development}

Lack of the Awareness of the Importance of Counselors' Status. Many colleges choose the students who just graduated as counselors. Due to the lack of the awareness of the importance of counselors' status, many colleges don't have specific requirements for working experience when they employ counselors. The switch to teachers makes the students who just graduated unfamiliar with the functions and working environment of counselors' job, which will make them puzzled at the work. In their practical work, there will be some problems. According to a survey, the average age of the college counselors is 30 years old, the oldest of them is 54 years old and the youngest is 22 years old. Those who between 41 and 50 account for 8 percent of the total. Those who under 40 account for 92 percent of the total. And those who under 30 account for 62.1 percent of the total. It shows that on the one hand, the college counselors trend to be younger and younger, who are more energetic; on the other hand, there are few people who will stick to working as college counselors and college counselors with rich ideological and political education experience are in need.

College Counselors Are Busy with Various Daily Work and Lack of Efforts and Time for Ideological and Political Education. It is stated explicitly in the Regulations on the Constructions of the College Counselors by the Ministry of Education that college counselors are the backbone of ideological and political education for college students, are the organizers, implementers and instructors of daily education and management of college students as well. College counselors should strive to become the life mentors and close friends for the healthy growth of college students. And during the detailed work, college counselors usually resort to more management but less education and are busy with daily work, resulting in the fact that college counselors do not have the 
time and the energy to study academic issues, ideological and political education, guidance of psychology and careers. Their professional competence and professionalism need to be further improved.

College Counselors' Professional Identity Needs to Be Further Improved and Space for Career Development to Be Further Expanded. Compared with professional teachers and researchers, college counselors lack the platform for participating in scientific research in detailed work, therefore, it is difficult and slow for them to get promoted in the academic title. Some college counselors may feel inferior to other professional teachers, fewer wages and other benefits than professional teachers and career prospects are not as good as professional teachers, which has some certain influence on the professional self-identity. At the same time, some colleges don't have enough awareness of re-education and professional construction for capacity and lack policies and funds-supporting measures. Colleges don't form relevant plans and vision that suit for their own development and students' interests, which has led to a lot of outstanding academic staff do not want to join the work of college counselors, meanwhile some excellent ones prefer to engage in other professional jobs and fields which have much development space. Such things do influence college counselors' own work and career development. In addition, college counselors are facing great pressure in job promotion. Some colleges are facing situation that the number of divisions and cadres has exceeded the standard, which makes the college counselors feel stressful and worried about the job promotion.

Occupational Access Is Not Scientific Enough and the Proportion of College Counselors in Relevant Disciplines Is Low. According to a survey, college counselors with philosophy and social science (including ideological and political education) major account for 9.6 percent of the respondents and those with pedagogy, psychology and sociology account for 3.8 percent. These two majors are close to the major requirements of college counselors but the sum of the two only accounts for 13.4 percent, which is relatively low. College counselors are an important team in students' ideological and political education, career planning and guidance, daily education and management as well as counseling students' psychological health. The daily work of college counselors has the characteristics of broad content and strong randomness. The work of college counselors has certain regularity and scientificity. Only those with certain level of ideological and political education, vocational skills and related profession literacy can be competent for the practical work. In theory, college counselors must have qualities and knowledge system of education, psychology, management, political science and other professions. But according to the present situation, there is still a great distance from the ideal state.

\section{The Countermeasure of College Instructors ' Career Development}

Colleges Do Improve the Awareness of Importance of the College Counselors' Position to Attract Talents into the Cause of College Counselors. On the one hand, government and relevant departments should from the macro level, standardize and clarify counselors' duties, improve the work of college counselors' assessment and evaluation mechanism, and vigorously enhance the identity of college instructors' work, the establishment of a sound college counselors' postpromotion mechanism, which will give college counselors confidence of work. On the other hand, the chief department of the college counselors at colleges should fully implement the spirits of the documents of central authorities and the relevant educational administrative departments. Combined with the practical situations of colleges, the colleges should establish and improve the relevant incentive mechanism to gradually promote and standardize the healthy and stable development of college counselors' work. The colleges should also increase the introduction of excellent college counselors and expand the scale of the college counselors "who are good both at political work and also professional work". The colleges should select from the professional teachers both engaged in the daily management of students, ideological and political education and those in daily teaching and scientific research work. College counselors like this are those with solid professional foundation and broad knowledge. Meanwhile they have a strong leading role for students' professional inspiration. 
Colleges should Figure out the Border of College Counselors' Work and Create A Good Working Atmosphere. The chief department of college counselors should clearly define the daily work of the college counselors together with relevant functional departments and make it more clear and detailed. Relevant departments should figure out the border of the work and allocate work that doesn't belong to college counselors to others. The colleges also guide college counselors in the daily ideological and political education and meanwhile carry out vigorously the study of ideological and political education, employment guidance, career planning, psychology and other aspects to gradually improve the level of college counselors' academic and scientific research and do a good construction of the college counselors' professionalism.

The Colleges should Perfect the Promotion Mechanism for Counselors and Enhance the Sense of Working Identity as College Counselors. At present, there are few college counselors who are associate professors and deputy directors. Colleges and relevant departments should offer policy support and help to college counselors in professional and technical positions, administrative duties for assessment and regularize the method and mechanism of college counselors' promotion. Colleges could try to set up independent evaluation indicators, evaluation criteria, and give protection to college counselors' in the system during evaluation. Meanwhile colleges also should try to establish the rank system and gradually achieve it under the situation that the number is allowed. Those who have worked for certain years and satisfy some certain standards can apply for section chief-level and deputy-level counselors, which can enhance the working enthusiasm and positivity of college counselors and improve the college counselors' sense of belonging and identity.

Colleges should Boost the College Counselors' System of Continuing Education and Enhance the Work of College Counselors' Professionalism. Many college counselors hardly participate in the training after working. They rely more on their working experience. However, with the development and advancement of time, the old experience may not be suitable for the current working environment; especially students of the generation after 90s have more personalities, thoughts and energy. Under these circumstances, college counselors are in need of learning and mastering new working methods. Departments of college counselors should actively strive to expand more for college counselors' continuing education, training, learning opportunities and channels, adopt more on-the-job training, theoretical discussion and exchange of experience. Departments of college counselors should also carry out work as attachment and exchange learning, which makes college counselors' career more open and professionalism richer. Departments of college counselors should focus on the training of the strengthening higher education, educational psychology, ideological and political education, applied psychology, group counseling, social work, student daily affairs management, career planning and employment guidance, party building and other aspects. Also the department should make efforts to improve the college counselors' ability to use their own professional skills and knowledge to solve practical problems.

\section{Colleges Should Establish and Improve the Incentive Mechanism for College Counselors to Promote Their Work Enthusiasm of the College Counselors}

Motivation is an important means of college counselors' management. To motivate college counselors is to satisfy the needs and desires of counselors by a certain means, which is used to improve working enthusiasm of the college counselors and stabilize the team of college counselors. Meanwhile colleges should guide more excellent talents to join the college counselors' team to improve the quality. The college should try to establish Four in One Motivation Method. That is material motivation, honor motivation, promotion motivation, entertainment motivation. As for material motivation, those counselors who perform well in practical work and earn good reputation should be given material reward. The college could try to take a certain amount of money dedicated to rewarding excellent college counselors from Student Affairs Office. As for honor motivation, the college should motivate the college counselors through voting "Outstanding Political and Ideological College counselors ", "Top Ten College Counselors ", "Management Model", "My Favorite College Counselor". As for promotion motivation, according to the ideological and moral quality of college counselors, the level of teaching and educating people, the level of education, the 
level of services, the completion of the practical work and the year-end assessment, combined with the standard of the title of promotion, the college should give excellent college counselors promotion timely. As for entertainment motivation, the college should offer free tour, quality development, study tours and others as rewards.

\section{The College Should Regard the College Counselors' Vocational Skills Contest as a Platform to Gradually Enhance the Professional Level}

The Standard of College Counselors' Professional Competence (Interim) issued by the Ministry of Education of the People 's Republic of China in March 2014 further explains college counselors' career profile, basic requirements, the level of competence standards and make further requests about the professionalism of college counselors. The college should take this opportunity to learn the quintessence and connotation of the documents. The Student Affairs Office should, combined with the actual situation, hold college counselor' vocational skills contest regularly so that it can promote the college counselors' learning, management and teaching. The relevant department could integrate various types of problems encountered in the actual work and simulate to solve these in the form of contest. This can gradually help improve college counselors' ability of solving complicated problems in practical work. College counselors' should focus on work of daily talk with students, dealing with emergency, concern about students of special groups and so on.

\section{Colleges Should Establish a Learning-Oriented College Counselors' Organization to Improve the Comprehensive Quality}

On the one hand, Student Affairs Office should have the concept and ability of building a learning college counselors organization and improve their comprehensive quality through organizing the meeting to learn Theory of bi-weekly. On the other hand, the department should guide college counselors to establish the concept of lifelong learning, lifelong thinking and guide college counselors to form new concept and idea of learning of professional skills that senior college counselors need. In the atmosphere that all the counselors learn together, the department gradually guides the college counselors to develop the ability of innovative thinking and awareness and gradually promote the growth and development of college counselors.

\section{Acknowledgements}

Project: Students work research branch of China's higher education institute "in 2016 university students work study general subjects: higher school counselor team construction of specialized research" (project approval number: LX2016Y013)

\section{References}

[1] Ministry of Education of the People's Republic of China. The Standard of College Counselors' Professional Competence (Interim) [Z] 2014.

[2] Cui Zhenqiong, The Problems and Solutions of Counselor Staff Construction in Higher Education Institution of China [D], Huazhong University of Science and Technology

[3] Ministry of Education of the People's Republic of China. Provisions on the Construction of College Instructors [Z] 2006.

[4] Zhou Xinyong, the Research on Construction of College Counselors in China [D]. Full - text Database of Excellent Chinese Master Dissertation, 2008, (2).

[5] Tang Linxia. Survey of Incentive System for Counselors in Higher Education Institution Study and Reflection on One Program [D]. East China Normal University. 2006.

[6] He Jiang, Research on professional training and professional construction of college counselor 
team

[7] Zhou Caixia, Research on the job burnout of college instructors under the trend of professional development

[8] Yang Yageng, Research on the career development of College Instructors in China

[9] Zhou Xinyong, Research on the professional construction of college counselor team in our country

[10]Zhang Zhi, On the professional development of College Counselors in China 